\title{
RESUMEN / SUMMARY
}

\section{SEBASTIAN COLL}

\section{"Empresas versus mercados. Un boceto para una bistoria de la empresa"}

Partiendo de la pregunta de qué puede aportarle a un estudiante de económicas o empresariales la historia de la empresa, el artículo defiende que esta aportación puede ser muy positiva, siempre que quienes impartan la materia adopten un enfoque más analítico que simplemente descriptivo. La naturaleza de la empresa y las causas y consecuencias de los cambios en la organización y el tamaño de la misma deberían ocupar, para ello, una posición central en sus explicaciones, mediante un equilibrio entre teoría e historia. En una primera parte del artículo se ofrece una panorámica de las teorías acerca de la naturaleza de la empresa, con especial atención al enfoque costes de transacción, y de la business bistory norteamericana, centrada en la empresa de ese país a lo largo del último siglo. En una segunda parte se presentan algunas reflexiones y sugerencias para extender este tipo de análisis a otros países y épocas.

\section{"Business versus Markets. A Sketch for a Business History"}

Starting from the question about the potential contribution of entrepreneurial history to the general formation of the students of economics and business, this article contends that this contribution may be very positive, provided that an approach more analitic than merely descriptive is adopted on the teachers' side. For it, the nature of the firm and the causes and consequences of changes in her organization and size should occupy a central place in their explanations, by means of a balance between theory and history. In the first part of the article a review is provided of the theories on the nature of the firm, with special focus on the transaction costs approach, and of the American business history, devoted to the study of the enterprise in that country along the past century. In a second part, some thoughts ans suggestions are given in order to extend the same kind of analysis to other countries and periods. 
RAMON SANCHEZ GONZALEZ

"El crédito rural: los censos (Estudio del préstamo censal en la comarca toledana de la Sagra en el Setecientos)"

Los censos constituyen un instrumento crediticio cuya valoración ha sido objeto de numerosas controversias, tanto por los economistas de la época como por los historiadores actuales.

Con este trabajo intentamos acercarnos a su conocimiento, analizando aspectos como la distribución geográfica de los censatarios, la sociología tanto de los acreedores como de los deudores, las cuantías que se prestan, la hipoteca con que se cargaban o la redención de los censos. Se pretende ver qué incidencia tuvo en la comarca de la Sagra, durante el siglo XVIII, para poder sacar unas conclusiones que nos permitan emitir un juicio sobre sus ventajas o inconvenientes como instrumento de préstamo.

Como fuente principal se han utilizado de forma exhaustiva las escrituras de imposición y de redención de censos existentes en los protocolos notariales del Archivo Histórico Provincial de Toledo.

\section{"Rural Credit: The Censos (Study on Mortgage in La Sagra Region of Toledo in the Eighteenth Century)"}

The censos constitute an instrument of credit the assessment of which has been the object of numerous controversies on the part of both economists of the period and present day historians.

The aim of the work here presented is to increase our knowledge of them, analyzing aspects such as geographical distribution of the lienees, the sociology of both creditors and debtors, the amounts of the loans, the mortgages against wich they were charged or their redemption. We attempt to discover their incidence in the region of La Sagra during the eighteenth century so as to arrive at conclusions wich will allow us to judge their advantages and disadvantages as a means of loan.

As the main source of information we have made exhaustive use of the deposit and redemption deeds of the censos to be found in the legal protocols of the Provincial Historical Archive of Toledo.

\section{CONCEPCION DE CASTRO \\ "Mercado y sociedad estamental en Campomanes"}

Las ideas económicas de Campomanes no se explican sólo en función de las corrientes de pensamiento económico que le fue dado conocer desde la España de su época; conviene considerar también su trayectoria vital y profesional. Como fiscal $-y$ más tarde gobernador - del Consejo de Castilla, el hidalgo asturiano fue un personaje encajado en el sistema social y político del Antiguo Régimen. Así, trató de introducir en la economía española las dosis de racionalidad del mercado que aquel sistema podía soportar; pero no fue más allá. 
Campomanes fue un agrarista al modo prefisiocrático, preocupado por la estabilidad del campesinado arrendatario en las explotaciones. Pero veía la necesidad de impulsar conjuntamente la producción agrícola y la manufacturera. Luchó, pues, por extender la formación profesional, por liberalizar los mercados frentc a tasas, controles, privilegios y monopolios. Y apoyó la creación de un Banco Nacional con la esperanza de que agilizara el ahorro y fomentara la producción.

\section{"Market and Old Regime in Campomanes"}

Campomanes economic ideas can not be adequately understood only in tcrms of the economic thought prevailing in 18th century Europe; it is also nccessary to consider his origins, life and professional progress. As a general atrorney -and, later, as governor- of the Council of Castile, the Asturian gentleman was perfectly fitted in the social and political system of the Old Regime. He attempted to introduce in the Spanish economy the elements of market rationality that the system could accept, but he did not go beyond.

Campomanes was neither a mercantilist nor a physiocratic economist. He thought necessary to promote both agriculture and manufacture and he was always worried with social problems. Campomanes fought to stabilize tenant-farmers on the land and to extend technical education among people; he tried to promote free markets against official prices, controls, privileges and monopolies; and he supported the creation of a public bank in the hope that it would help to movilise savings and to foster producrion.

\section{CANDELARIA SAIZ PASTOR} "La revolución liberal española y el control de la Hacienda cubana (1826-1843)"

A través de un análisis de la utilización de los recursos públıos de la isla de Cuba, por los liberales españoles, el presente artículo pretende relacionar el mundo colonial con la revolución liberal en España. El trabajo presenta una serie de ingresos y gastos de la Hacienda cubana entre 1826 y 1840 . Su estudio pone de manifiesto la evolución al alza de los ingresos fiscales de la isla en ese periodo. En cuanto a los gastos, merece reseñarse la importancia del capítulo de sobrantes o cantidades remitidas a la península, lo que significa la disposición de una buena parte de los recursos públicos de la colonia para solventar necesidades de la metrópoli.

\section{"The Liberal Spanish Revolution and the Control of Cuban Public Finance (1826-1843)"}

By using an analysis of the utilization of public resources by the liberal spanish on the island of Cuba, the current report attempts to link the colonial world with the liberal Revolution in Spain. The study shows a series of incomes and expediture by the Cuban Colonial Treasure between 1826 and 1840. Its study reveals even increasing fis- 
cal incomes on the island during this period. Concerning expenditure, the important chapter of sobrantes or cantidades remitidas a la peninsula, deserves recognition, as it shows the availability of a good proportion of the public resources of the Colony to sctele Metropolis' needs.

\section{ELENA. LEGORBURU FAUS \\ "La industria guipuzcoana entre 1930 y 1936: Incidencia de la crisis económica"}

En 1930, la provincia de Guipúzcua figuraba entre las más prósperas e industrializadas de España. Durante los años siguientes se vio afectada por una serie de circunstancias que motivaron la depresión de su actividad fabril: la contracción del comercio exterior, el cambio de regímenes políticos, el nuevo marco de relaciones laborales... Todo ello repercutió de forma muy particular en el ámbito guipuzcoano, caracterizado mayoritariamente por la pequeña dimensión de sus empresas, la diversificación productiva, su conexión con los mercados exteriores. Como telón de fondo, nos hallamos ante la incapacidad de los distintos gobiernos para armonizar los intereses dispares y encontrados de las diversas áreas económicas de España.

La confección de este trabajo ha contado con la inestimable orientación de los profesores Montserrat Gárate, Pablo Martín Aceña y Luis Castells. Su labor, no obstante, no habrá podido impedir posibles incorrecciones cuya responsabilidad cabe atribuir tan sólo a su autora.

\section{"The Guipuzcoa's Industry between 1930 and 1936: The Impact of Economic Crisis"}

In 1930 the province of Guipúzcoa stood amont the most prosperous and heavily industrialized in Spain. In the following years it found itself affected by several circunstances which brought about the fall of its manufacturing activity: dwindling foreign trade, a shift of the political systems, a new frame of labour relations... All that had a very special effect throughout Guipúzcoa, mostly characterized by the small size of its enterprises, the diversification of its production and its close links with foreing markets. As a backdrop lies the inadequacy of the different governmentes to harmonize the disparate and conflicting interests of the mixed economic areas of Spain.

The making of this work has had the invauable guidance of professors Montserrat Gárate, Pablo Martín Aceña and Luis Castells. Noretheless their assistance may not have prevented possible maccuracies whose responsability is to be solely attributed to its author. 